\title{
PROBLEMS AND POSSIBLE DIRECTIONS OF THE SUSTAINABLE RURAL DEVELOPMENT OF REPUBLIC OF SERBIA
}

\begin{abstract}
Sustainable development of rural areas is very significant for the economic development of the Republic of Serbia. Reduction in the number of citizens in rural areas and neglect of agriculture in the previous years have led to numerous economic and social problems. The most important among them include the unfavorable demographic trends, undeveloped infrastructure, small agricultural farms that are not market oriented, a low productivity level of agriculture and a low income per farm, a large share of agriculture in rural economy, a low degree of diversification of rural economy, insufficient investment into rural areas, etc. Such condition is unsustainable because it causes more difficult life and work conditions in rural areas. Rural areas in the Republic of Serbia are the subject of this analysis. The aim of the paper is to examine possibilities of further development of rural areas in Serbia. The methods which will be used in the paper include the methods of synthesis, analysis and compilation.
\end{abstract}

Key words: sustainability, rural areas, underdevelopment, rural development.

JEL classification: $Q 20, Q 40, Q 50$

\section{ПРОБЛЕМИ И МОГУЋИ ПРАВЦИ ОДРЖИВОГ РУРАЛНОГ РАЗВОЈА РЕПУБЛИКЕ СРБИЈЕ}

\section{Апстракт}

Одрживи развој руралних подручја представља велики значај за привредни развој Републике Србије. Смањење броја становника у руралним подручјима и запостављање пољопривреде годинама уназад довело је до бројних економских и соиијалних проблема. Најважнији међу њима су неповољни демографски трендови, неразвијена инфраструктура, уситьена пољопривредна газдинства која нису тржсишно орјентисана, ниска стопа продуктивности пољопривреде и низак приход по газдинству, висок удео пољопривреде у руралној привреди, низак степен диверзификачије руралне економије, недосвоље инвестиичје у рурална подручја и сл. Такво стање је неодрживо јер узрокује све теже услове живота и рада у раралним подручјима. Предемет анализе су рурална подручја

1 j.velickovic90@gmail.com, ORCID ID 0000-0002-3719-0114

2 sonja.jovanović@eknfak.ni.ac.rs, ORCID ID 0000-0003-0937-9195 
у Републици Србији. Циљ рада је испитати могућност даљег развоја руралних подручја у Србији. Методе које ће бити коришћене у раду су метод синтезе, анализе и компилације.

Кључне речи: одрживост, рурална подручја, неразвијеност, рурални развој.

\section{Introduction}

In modern conditions sustainable development becomes the main concept of development. The concept of sustainable development connects the care for the living world on the planet and the preservation of the natural capacities with the social and economic challenges. Although there is no unique and universally accepted definition of sustainable development, there is global awareness about the need to introduce this concept. The most frequently used definition was created by the World Commission on Environment and Development back in 1987. According to this definition, "sustainable development is an economic and social development which meets the needs of current generations without jeopardising the opportunities of future generations to meet their needs" (WCED, 1987, p.43).

Rural development is one of the catalysts of sustainable development. Development of economic activities in rural areas plays a significant role in the development of every country, but they also have a very important role in the preservation of environment since they represent the places which are inhabited by rural population. Sustainable rural development is a mixed developmental concept which is created by an integral merging of sustainable and rural developments and represents a particular combination of their basic elements.

The concept of sustainable rural development includes three main dimensions of developmental sustainability: economic, social and ecological dimensions of rural development (Stojanović, Manić, 2009, p.43.). The economic dimension of rural development refers to the economic growth through the achievement of vitality, efficiency and effectiveness of the economic activity in the rural areas. The social dimension of rural development refers to the social progress through the improvement of the human potential and the creation of equal opportunities for a living in rural areas. The ecological dimension of the rural development refers to the protection of environment through the management of natural resources and the pollution in rural areas. Ecological sustainability and economic sustainability are basic assumptions of the survival of rural areas. The society expects from rural population to take care of and protect the environment. Therefore, one of the goals of sustainable development is the development of highly competitive agriculture with regard towards the ecological question (Đekić, Jovanović, Krstić, 2011, p. 634.).

The rural areas of the Republic of Serbia have certain resources for a successful application of the concept of sustainable rural development. However, there are also numerous limiting factors of development, so there is a need for large structural changes and significant investments into this field. The aim of this research is to analyse possibilities of implementation of the concept of sustainable development in rural areas in Serbia. The purpose of the paper is to show the state in which the Serbian rural space is currently and to explore the possibilities for its improvement. 


\section{Main charactecs of the rural areas in the Republic of Serbia}

A rural area is a specific economic, social and spatial area, i.e. it is a specific segment of economy, society and space. Not only in Serbia, but also in Europe, rural areas occupy significant amounts of territory (Đekić, 2010, p. 207). According to the definition of OECD, rural areas occupy $85 \%$ of the territory of Serbia, more than $50 \%$ of the population live in them and they constitute more than $40 \%$ of the GDP of Serbia. The population density in rural areas is 63 per $\mathrm{km}^{2}$ and it is smaller than the national average for a third (Bogdanov, 2007, p.31).

The rural areas of Serbia fulfil all the prerequisites for a successful implementation of the concept of multifunctional agriculture and integral rural development: the wealth of natural resources, the diversity of rural areas, the preserved rural ambient spaces and tradition, and the unused potential for the development of non-agricultural activities in villages (Ristić, Vujičić, 2011, p. 65). However, there are also numerous limitations: "negative demographic trends, undeveloped infrastructure, small and non-market oriented agricultural farms, a low productivity level of agriculture and a low income per farm, a large share of agriculture in the rural economy, a low degree of diversification of the rural economy, insufficient investment into the rural areas, high unemployment ratio, insufficient capacities for trade, etc.” (Ristić, 2013, p. 232).

"The rural areas of the Republic of Serbia are characterised by a high degree of differentiation in regard to: the natural, infrastructural and other conditions for agricultural production and the development of other economic activities, the proximity of the market and the conditions for placing a product on the market, as well as the size and the morphology of communities." (Bogdanov, 2007, p. 60). That is the reason why rural areas, within the Strategy of the Rural Development of the Republic of Serbia, are divided in the following manner: (MAFWM, 2009, p. 6-9)

Region 1 - highly productive agriculture and integrated economy;

Region 2 - economy sectors typical for smaller urban areas with agriculture, in which there is an intensive use of workforce;

Region 3 - branches of economy oriented towards the use of natural resources, primarily mountain areas;

Region 4 - large tourist capacities, but bad agricultural structure.

Therefore, development possibilities of rural areas are different and they depend on: the geographic position and accessibility (areas which are closer to urban areas, important roads, processing capacities and the market have development advantages), natural conditions and potentials (altitude, climate, soil, forest cover, biodiversity, water resources, mineral resources), human and material resources (infrastructure, economy-related capacities, the number and the level of expertise of workforce, the degree of development of public services, the size and morphology of the region) and the social capital and interactions (cultural particularities, the attitude towards tradition, modernisation, horizontal and vertical cooperation, etc.) (Popović, 2011, p.35).

On the basis of the SWOT analysis (table 1), which includes the rural areas of Serbia, there are advantages which can be transformed into possibilities and contribute to a more dynamic growth and development of these rural areas. It can be noticed that the weaknesses are more dominant in relation to the advantages, and that the rural areas 
of the Republic of Serbia are expecting a large number of chances and dangers from the surrounding environment that they will have to face. (Ristić, 2013, p. 232).

Table 1 shows that the strengths of the rural areas are reflected in the favourable geographical position, diversity and attractiveness of the ambient, rich cultural heritage, development of the rural tourism, etc. As far as the weaknesses and threats are concerned, a significant part includes a lack of funds, low infrastructural equipment, unfavourable social structure, socio-economic and political instability, etc.

Table 1. The SWOT analysis of the sustainable development of the rural areas

\begin{tabular}{ll}
\hline STRENGTHS & WEAKNESSES \\
\hline Geographic location; & Lack of financial funds; \\
$\begin{array}{l}\text { Diversity and attractiveness of the rural ambient; } \\
\text { Biodiversity; }\end{array}$ & Unfavourable demographic trends; \\
Rivers, lakes, thermal springs, and forests; & Inactive job market; \\
Rich cultural heritage; & Unfavourable social structure; \\
Preservation of traditional knowledge and technology; & Unused possibilities of the diversification of income \\
Gastronomy and hospitality of people; & at households; \\
& Insufficient utilisation of cultural heritage; \\
& Low infrastructure equipment; \\
& Restricted access to social services; \\
& Insufficient business integration; \\
& Inadequate volume/quality of production; \\
\hline OPPORTUNITIES & Inadequate waste management; \\
\hline EU integration; & THREATS \\
Inclusion into EU funds; & Socio-economic and political instability; \\
Sustainable use of resources; & Climate changes; \\
Economic diversification; & Irrational use of natural resources; \\
$\begin{array}{ll}\text { Development of small and medium enterprises and } \\
\text { entrepreneurship; }\end{array}$ & Competition on the national and the international \\
Development of rural tourism; & markets; \\
Organic food, traditional food and indigenous products; & The lack of qualified workforce; \\
Export; & Insufficient availability of financial resources; \\
&
\end{tabular}

Source: MAFWM, 2009

\section{Problems of the rural areas in the Republic of Serbia}

In modern conditions, the rural areas of the Republic of Serbia are facing great challenges which are the consequence of both the socio-economic occurrences it has faced and the sociological changes experienced by the people from these rural areas. In this part of the paper, the focus is on the problems which are characteristic of the rural areas of the Republic of Serbia:

- Depopulation and unfavourable age structure;

- Unfavourable educational structure of the rural population;

- Inadequate economic structure,

- Traditional structure of production and disorganisation of agricultural producers;

- Unemployment, low income and poverty;

- Insufficiently developed rural infrastructure; 
- Devastation of material resources;

- Lack of appropriate institutional, organisational and planning support for the rural development;

- Irregular and poor incentives proposed to the rural areas.

Depopulation and unfavourable age structure are the most significant demographic characteristics of the rural areas of the Republic of Serbia which have occurred as a consequence of placing more and more emphasis on urbanisation and industrialisation. (Spalević, 2009, 134) Tendency towards more and more of the so-called internal migration of the population from rural into urban areas, a low rate of the population growth, strengthening of economic activities and certain political events have influenced the current unfavourable structure of population in the rural areas.

Besides the decrease in the number of the total population of Serbia during the period between 2002 and 2011, the rural population has also declined. In the period from 2002 to 2011, the rural population has decreased by $10.9 \%$. According to the results of the census, the rural population makes up $40.6 \%$ of the total population of Serbia (MAFWM, 2018). From a regional aspect, the most expressed decrease in the rural population has been noted in the rural areas of South and East Serbia. Depopulation trends also lead to more expressed gender differences. "Namely, the decrease in the number of people in the rural areas is more expressed with female than male population" (Đurić, 2018, p.71). The departure of young women from the rural areas directly jeopardises the survival of the village, because women perform multiple functions in the development of the village: working at an agricultural property and its household, giving birth, i.e. the population rebirth of the village, and maintaining the family and giving men the opportunity to start their families and have heirs.

The change in the age structure of the population in Serbia has moved towards the lower share of the young and the increase in the number of old people. The median age of the rural population is 41.6 years, and in more than 200 villages there are no people younger than 20 years (www.minpolj.gov.rs). The causes due to which the young leave agriculture and rural areas are: the decrease in agricultural production, hard labour in agriculture, lack of security in the individual sector in agriculture, production risks. The age structure of the population in the rural areas is significantly unfavourable in central, and especially the south-eastern parts of the country, in relation to the regions of Belgrade and Vojvodina (MAFWM, 2018, p. 19).

The depopulation trend is accompanied by a parallel process of deagrarianization of the rural areas, i.e. the lower share of agricultural population in the total population. According to the census from 1981, agricultural population made up around $25 \%$ of the total population, while in only two decades, the agricultural population decreased to around $11 \%$ of the total population of the Republic of Serbia (MAFWM, 2018, p.19).

Educational characteristics of the rural population are significantly more unfavourable than the characteristics of the urban one. Namely, in the rural population, there are predominantly people with high-school education $(42.4 \%)$, which is a significantly higher level in relation to those who only have an elementary school diploma $(27.7 \%)$ or do not have any formal education (23.4\%) (MAFWM, 2018, p.19). Such educational structure reflects negatively on the acquisition and implementation of new technologies in agriculture, innovation, entrepreneurship and all other segments which secure progress of 
this economic activity and rural environment in general. If the analysis of the educational structure of the rural population is conducted by taking into account the gender, the situation is even more unfavourable. Within the rural female population, more than half are individuals without any qualification, i.e. without any education or they only finished elementary school (Đurić, 2018, p.73). A digital gap between rural and urban areas is expressed. Only $20 \%$ of the rural population is computer literate and $14 \%$ partially knows how to work on a computer, while nearly $66 \%$ is still computer illiterate. The presence of a broadband internet connection is $52.4 \%$ in urban population, and $28.5 \%$ in rural population. This has a negative effect on the quality of the workforce and the overall business the rural areas (Government of the Republic of Serbia, 2014, 39).

The economic structure of the rural areas of Serbia depends largely on natural resources. The participation of the agricultural sector is particularly significant. Also, mining and energetics, and a small share of tertiary sector are represented. Natural conditions enable the development of intensive agriculture. It has, as such, been developed in Vojvodina, while its extensive character has developed in the mountainous regions (MAFWM, 2018, p. 20).

A significant problem occurs with the traditional structure of production and disorganisation of agricultural producers so that local communities do not have autochthonous, recognisable and competitive products, which can be successfully promoted on the global market. Such condition is unsustainable because it causes, in the local environments, more and more difficult conditions for living and working, the decay of the existing agricultural households, the loss of function of agricultural land, economic and social decay, the loss of identity of the local communities, exposure to harmful occurrences, devastation of cultural and traditional heritage, bad economy management, unemployment, etc. (www.invest.negotin.rs).

Unemployment is an important problem in rural areass. Although rural economy has a high unemployment rate, it is, however, in a somewhat more favourable position than the urban areas (MAFWM, 2011, p.10). The reason for this is the fact that rural environments provide more opportunities for employment of individuals with lower education, which refers particularly to their work in agriculture. A dominant part of the actively working rural population in Serbia is working in agriculture (Bogdanov, 2007, p. 32).

The incomes of the rural households largely (35-42\%) come from the incomes earned due to employment, and pensions occupy the second place (Government of the Republic of Serbia, 2014, p. 40). For most small agricultural farms, agriculture does not provide a stable source of income. In order to reduce the level of business risk and to stabilise income, these farms are mostly oriented towards a diverse structure of production. On the other hand, those agricultural farms with a significant scope of agricultural work, higher prevalence of younger agriculturally-oriented working population, and a better position on the market, are primarily oriented towards greater specialisation of its production.

In the Republic of Serbia poverty is significantly higher in the rural areas. Rural population, which is more exposed to poverty, mostly include: farmers in the mountainous regions, elderly and single-person households, internally displaced individuals in the rural areas, employed rural population who do not earn their income from agriculture, or they earn incomes from agriculture, but not outside of it (Ristić, 2018). Regional differences in the distribution of rural poverty are significant and they follow the relation which exists among the regions when it comes to the total poverty: the situation is the least favourable 
in South and East Serbia, and more favourable in the AP Vojvodina (Government of the Republic of Serbia, 2014, p. 42).

The rural infrastructure in the Republic of Serbia is not developed enough. Rural areas are characterised by a low number of roads, poor communal infrastructure and other important elements of the standard of living. The infrastructure on the municipal level is more or less developed with great potential for further development; however, it is also accompanied by large limitations such as a low amount of information about the needs, characteristics and benefits of the rural infrastructure, which contributes to the unresolved question of the water supply system, telecommunication and other problems that prevent further development (MAFWM, 2011, p. 23).

The road infrastructure is not distributed evenly on the territory - many areas are far away from the main roads and highways. The current state of the water-management infrastructure is unfavourable, which is also confirmed by the fact that only around 5\% of agricultural lands are equipped for irrigation. The communal standard of villages lags behind the standard in the cities. When it comes to supplying the population with drinking water, it is pointed out that $40 \%$ of the population uses water from their own wells (Spalević, 2009, p.137 ). A significant problem of the rural areas is also the sewage system. The transportation of garbage and other solid waste relies on the individual activity, i.e. landfills are formed on the sides of the roads, rivers, near the villages, and they represent a significant ecological problem. The condition of the objects of public services is unsatisfactory on the entire rural territory of Serbia. The work of the secondary rural services such as preschool institutions, postal offices, banks, sports halls has been evaluated as the worst. Very often, several rural areas are oriented towards a single primary school while there are almost no preschool facilities (Spalević, 2009, p.138).

"According to the results of the 2012 census, there are 631,522 agricultural farms which use 3.437 million hectares of agricultural land. The average size of the used land per farm is 5.4 hectares" (MAFWM, 2018, p.77). "Among the registered agricultural farms, $99.6 \%$ of them are owned by individual natural persons, who use $82 \%$ of the territory. The average size of agricultural farms is 4.5 hectares and it significantly varies among regions. The other $0.4 \%$ of farms are owned by legal entities which use $16 \%$ of the territory and have an average size of 210 hectares per farm" (Kvrgić, Ristić, 2018, p.32, according to: MAFWM, 2014, p. 10). Almost one half of the farms which are registered in the form of legal entities that perform agricultural activities are operating in the region of Vojvodina, while the form of individual entrepreneurship of this activity is mostly present in the regions of Šumadija and West Serbia (MAFWM, 2018, p. 21). "Therefore, there is a problem of too many small plots of land on the farms owned by families. The average number of plots per farm is over 6 , with the average size of 0.98 hectares per plot" (Kvrgić, Ristić, 2018, p.32). Around 77\% of the total number of agricultural farms on the territory of Serbia are livestock breeders. In the decades to come, the number of farms is expected to drop down further, due to aging and vanishing of households without heirs.

The rural areas of Serbia are characterised by degradation of ecological integrity, i.e. devastation of material resources - pollution of waterways and exhaustion of water sources, pollution by solid waste, decay and impoverishment of the recognisable architectural heritage, devastation of agricultural and forest lands, uncontrolled changes in the soil treatment, uncontrolled deforestation, reduction of biodiversity, ecological problems 
caused by increased pressure and the use of space due to additional activities (rural tourism, production and processing - small enterprises) (Republic Office for Development, 2009, p. 25).

The rural areas of the Republic of Serbia are facing the lack of appropriate institutional, organisational and planning support for the rural development, i.e. spontaneous and unplanned urbanisation, an unclear strategy and policy of development of the rural areas, the lack of planned restructuring of villages, the significant lack of planning, project, professional civil engineering and inspection activities in the rural areas, and an insufficiently developed information system (Republic Office for Development, 2009, p.25).

In addition, there are poor, irregular and unsystematically created incentives for our rural areas from a poor national budget and an even poorer agricultural budget, which leads to an obvious conclusion that the main obstacles for the development of the Serbian rural areas are systematic and structural, as well as deep and permanent (Mitrović, 2015, p.210). The solution to the problem of rural development should be sought through an integral approach, which requires a multi-sector cooperation at all levels (local, regional and national), and a combination of measures that could be the jurisdiction of the ministries, regional or local authorities. Besides this, it is necessary to define a programmed framework, which will contain clear goals, expected results, and clear establishment of indicators and their monitoring in order to review successfulness and, if needed, to consider corrective measures.

\section{Possible directions of the sustainable rural development in the Republic of Serbia}

Finding opportunities to improve the condition of the Serbian rural areas is not simple, and even more developed countries have not been able to solve the aforementioned problems although they have a more proactive policy of rural development than the one in Serbia. The main aim of the development of the villages and rural areas of the Republic of Serbia is the increase in life quality in rural areas through preservation, renovation and sustainable development of their economic, social and ecologic vitality, as a result of decentralisation of cities and municipalities (Government of the Republic of Serbia, 2010, p.134). The following points could be singled out as possible directions of the sustainable rural development in the Republic of Serbia:

- Renovation and development of rural infrastructure;

- Stimulation of agriculture based on knowledge, i.e. organic agriculture;

- Establishment of cooperatives;

- Development of rural tourism;

- Production and use of renewable sources of energy;

- Development of the agro-business system;

- Development of small and medium businesses;

- Education on sustainable rural development;

- Improvement of legal regulations.

"An important priority for the sustainable rural development is the improvement of the rural infrastructure (roads, water management, sewage, electrical energy, and 
information and telecommunication services).” (Ristić, 2013, 242) Due to the funds from the National Investment Plan for agriculture in Serbia, the projects of renovation and construction of village infrastructure are being realised, which also includes construction and renovation of water supply and sewage networks, reinforcement of the power grid, construction of agribusiness centres, reconstruction of roads, etc. (Đekić, 2010, p.207). Besides the National Investment Plan, a part of the activities on the development of rural infrastructure is funded from the funds of the Ministry in charge of the economic activities, donation projects and local self-government units.

Research shows that agriculture which is based on knowledge, i.e. agriculture which produces quality foods, organic agriculture, indigenous products with the protected geographical origin, traditional specialties, as well as functional food for the prevention or reduction of the risk of certain diseases, creates opportunities for the development of industry, transport, storage, trade, services and other economy sectors in the rural areas (Ristić, 2013, p.238).

Since it is socially, economically and ecologically accepted, organic agriculture can contribute to the sustainable development of rural areas. (Ristić, 2013, 243) “According to the data from the Ministry of Agriculture, Forestry and Water Management of the Republic of Serbia, the organic production in 2017 took place on the total territory of 13,423 ha. The arable lands included in organic production in 2017 were 11,874.8 ha" (Organic Agriculture in Serbia 2017). Vojvodina is the region with the largest share of lands which are included in organic production, followed by the regions of South and East Serbia, and then, the regions of Šumadija and West Serbia (Organic Agriculture in Serbia 2017). In the period to come, the state needs to stimulate investments into this field, while it should encourage the production of products which are scarce in the world, especially in the EU.

Cooperatives have an important role in renovation and sustainable development of rural areas. However, the programmes of support for the cooperative sector, which have been provided by certain ministries in the previous years, have been operating on an ad-hoc principle, and they have been unsynchronised and systematically disorganised. Some of the key problems are: unresolved property relations, the question of cooperative property as a collective mode of private property, agricultural cooperatives in the Republic of Serbia do not have their own processing capacities, they have a harder access to the capital market, cooperation among cooperatives is not developed, etc. In the modern conditions, there is a growing number of associations but their power of negotiation is mostly low due to their dependence on the processing industry (Government of the Republic of Serbia, 2014, p.33).

In order to economically strengthen rural areas, it is necessary to create an environment that would increase work motivation of people. In this sense, the development of incentive programmes is needed in order to contribute to the introduction of new technologies and innovation which opens up space for entrepreneurship in which young people would participate. The priorities of development are shifted from agricultural to non-agricultural activities such as tourism, eco-industry, craftsmanship, etc.

The development of tourism in rural areas is an example of activities that can significantly contribute to achieving the goals of sustainable rural development. The potential in the form of natural and cultural assets can be significantly preserved and used in a sustainable way with the help of tourism in rural areas. Sustainable rural tourism produces revenue on a local level and integrates local communities with the aim of improving the quality of life and reducing poverty, it protects natural and cultural goods 
such as biodiversity, cultural heritage and traditional values, supports understanding and tolerance among cultures, aspires to greater energy efficiency and maintaining a healthy climate, avoids overconsumption of water and reduces the production of waste to the smallest possible amount.

Serbia has the base of the rural tourism, which has been developed over many years, especially in the West Serbia, Vojvodina and Central Serbia. The largest part of the territory of Serbia is rural where there are the most natural goods, as well as significant potential in the form of anthropogenic. These resources are extremely attractive for the development of rural tourism experience. The natural surrounding represents one of the strongest resources of Serbia and it should be protected and improved through the responsible development of tourism (The Master Plan of the Sustainable Rural Tourism in Serbia).

Rural tourism can play a significant role in the diversification of rural economy. On that way, tourism contributes to the increase revenue, improvement of the quality of life, preservation of the cultural heritage. With higher incomes much more can be done with nature conservation. Therefore, it is necessary: to invest in rural and tourist infrastructures, to adapt and build housing capacities which are of specific appearance and architecture, to bring investments into rural areas with a significant tourist potential, to educate those who work in rural tourism, to promote rural tourism at all levels, to strengthen public-private partnerships, to organise manifestations, together with the selling of specific products of a certain region (especially gastronomic and home-made products), to introduce additional attractive content, to adjust tourist offers to the specific demands of health, children, youth and family tourism, to encourage the education of women who live in rural areas so that they could be much more engaged and employed in rural tourism through old crafts and homecrafts. (Ristić, 2013, 244)

The production and use of renewable sources of energy (bio-mass, bio-gas, biodiesel, energy from the sun, wind, water, etc.) are being developed intensively, thus providing an additional income, but also employing people and providing other economic gains. It is the ecological reasons for the use of this type of energy which are emphasised. There is energy potential in the renewable sources of energy in the Republic of Serbia, but it is mostly unused. In Serbia, the largest potential, as a source of energy from renewable sources, belongs to bio-mass. However, agricultural producers are mostly led by the idea that the largest share of biomass should be ploughed in order for the soil to recover from the extraction of so many matters and thus prepare for a new season. On the other hand, in livestock breeding, biomass is most often used for animal bedding. The production of bio-gas is growing in Serbia, although it requires a lot of money to make and equip the gas facility. The Republic of Serbia encourages the construction of mini hydro-electric power plants which produce up to $10 \mathrm{MW}$ and it refers to them as the Green kilowatts. However, due to the economic reasons, there are not many farms in Serbia which use waterways to produce renewable sources of energy, the water is used for irrigation and livestock watering. The greatest potential for the utilisation of the wind energy is in the Košava region of Serbia.

"In order to stimulate broader applications for renewable sources of energy, it is necessary to create an incentive regulatory framework, to subsidise the introduction of an adequate equipment and facilities to use these sources of energy, to provide tax benefits and to educate the staff due to the lack of knowledge and experience in the production and use of alternative sources of energy in our country." (Ristić, 2013, 244) 
One of the directions of development can be to connect agricultural production with the processing industry, and service organisations, thus building an agribusiness system. Employing workers from rural areas in that capacity leads to an increase in the number of the so-called mixed households and the stay of a certain number of residents in these areas (Đekić, 2010, p. 206).

The development of the rural areas of the Republic of Serbia also depends on mutual activities of both social and private sectors. Besides supporting the economic development, The development of small and medium sized businesses will also increase employment. The advantages of SME are reflected in greater flexibility, quicker adoption of innovations, application of the methods of direct control and worker motivation, simple organisational structure and the fact that they can optimally be adapted to the comparative advantages of the region. Support to the development of SME would be enabled by tax exemptions, as well as help in the form of certain instructions and business-related information (Đekić, 2002, p.143).

Sustainable rural development, due to its complexity and multidimensionality, encompasses a wide spectrum of skills and disciplines. This is why education is one of the important factors in achieving sustainable rural development. It is important to provide knowledge and enable the spread of awareness of the importance of behavior and business in a way that will ensure sustainable rural development. It is necessary to educate the inhabitants of rural areas about all the consequences of irresponsible behavior and actions that endanger future development. The education for sustainable rural development implies learning about certain skills which need to be mastered in a practical way in order to conduct sustainability. This kind of education encourages creativity to make new development solutions in the domain of sustainability. Better engagement of the agricultural advisory service, as well as other organizations that can provide professional services and consultations is very important.

Institutional support is very important, which provides an environment for numerous improvements in behavior and action in the direction of sustainable rural development. There is a need for coordinated work of a number of institutions in the implementation of activities to ensure sustainable development. The organisations and institutions which have a significant role in sustainable rural development are various ministries and government organs led by the Ministry of Agriculture, Forestry and Water Management, which are responsible for sustainable rural development. Important role in coorinated activities have ministries and agencies responsible for the economy and regional development, finance, infrastructure, education, the environment, work and social politics, tourism, local government, as well as many more.

\section{Conclusion}

In accordance with the aim, the paper identifies several problems which the rural areas of the Republic of Serbia are facing. The most significant among them is the reduction of population and the departure of young people from the rural areas. The main reason why the young are leaving includes very hard conditions of life and work in rural areas due to insufficiently developed infrastructure, inadequate social structure, unavailable social services and large dependence on agriculture. The educational structure of rural population 
is very unfavourable, which slows down the acceptance of new technological solutions which would facilitate the working process.

The most important source of income for people in rural areas is from agriculture. Another characteristic of rural areas refers to the significant negative impact and degradation of natural resources. Also, he rural areas of the Republic of Serbia are facing a high unemployment rate and poverty. Besides this, the support for the development of entrepreneurship is very modest. The rural areas of the Republic of Serbia are faced with very modest investments, with insufficient institutional, organisational and planning support, as well as with irregular and small incentives. Problems should be approached in a strategic and systematic way. It is necessary to create a development plan for rural areas and provide resources and a favorable environment for its implementation.

The opportunity of fertile soil and beautiful nature should be used in the best possible way, thus keeping the population in the rural areas. The analysis used in the paper shows that the larger attractiveness of rural areas, as places in which young people live and work, can be achieved through the renewal and development of infrastructure, the improvement of social structure, the development of secondary rural services such as preschool institutions, post offices, banks, and sports halls. Stimulation of rural population towards a higher level of education is also very important for the development of rural areas. Of special importance is the training of a larger number of people and the implementation of modern technological solutions and innovations.

Another important thing for sustainable rural development is the encouragement of population to turn towards organic agriculture, i.e. the agriculture which produces healthy, high quality and safe food. Considering the fact that organic agriculture is economically, socially and ecologically acceptable, it can contribute to sustainable rural development. Rural population can acquire additional income through the production and use of renewable sources of energy. The construction of agribusiness centres is also important for the development of the rural areas. This way, the employment rate would increase, and poverty would be reduced, which would make rural areas more attractive for the young to live in.

Support for entrepreneurship in rural areas is one of the important issues. the development of non-agricultural activities is of great importance in order to provide additional employment and additional sources of income. One of the examples is the development of rural tourism which can lead to diversification of activities and reduction of poverty, improvement of the quality of life, preservation of cultural heritage and protection of the environment. Therefore, it is necessary to invest in rural and tourist infrastructures, to constantly improve tourist offers, to introduce new content, to organise manifestations and to invest into the renewal and development of accommodation capacities. Besides this, another significant point for the development of rural areas is the stimulation of rural population towards old crafts in order to develop unique, recognisable and competitive products, which can be successfully presented on the global market. 


\section{References}

Bogdanov, N., (2007) Mala ruralna domaćinstva u Srbiji i ruralna nepoljoprivredna ekonomija, UNDP, Beograd.

Đekić S. (2002.) Potencijalni razvoj ruralnih područja Jugoslavije, Regionalni razvoj i demografski tokovi balkanskih zemalja, knjiga 7, Niš.

Đekić, S., (2010) Agrarni menadžment, Ekonomski fakultet, Niš.

Đekić, S., Jovanović, S., Krstić, B., (2011) Komparativna analiza strategija održivog ruralnog razvoja zemalja u okruženju - osnova za kreiranje efektivne strategije održivog ruralnog razvoja u Srbiji, Ekonomske teme, br. 4, str. 633-649.

Đurić, K., (2018) Poljoprivreda i ruralni razvoj Srbije u procesu evropskih integracija, Poljoprivredni fakultet, Novi Sad

Kvrgić,G., Ristić, L., (2018) Unutrašnji izazovi održivog razvoja ruralnih područja Republike Srbije, Naučne publikacije državnog univerziteta u Novom Pazaru, serija B: Društvene \& humanističke nauke, vol. 1, br. 1, 28-46.

MAFWM, 2009.

Master plan održivog ruralnog turizma u Srbiji, https://futurehospitalityleaders.files. wordpress.com/2012/11/master-plan-odrzivog-razvoja-ruralnog-turizma-u-srbiji.pdf

Ministarstvo poljoprivrede, šumarstva i vodoprivrede (2009) Plan strategije ruralnog razvoja 2009-2013, MPŠV, Beograd.

Ministarstvo poljoprivrede, šumarstva i vodoprivrede (2011) Nacionalni program ruralnog razvoja od 2011. do 2013.godine, MPŠV, Beograd.

Ministarstvo poljoprivre, šumarstva i vodoprivrede (2018), Nacionalni program ruralnog razvoja od 2018. do 2020. godine, MPŠV, Beograd.

Mitrović, M., (2015), Sela u Srbiji - promene strukture i problemi održivog razvoja, Republički zavod za statistiku, Beograd.

Organska poljoprivreda u Srbiji 2017, https://serbiaorganica.info/organska-proizvodnjau-srbiji/.

Popović, V., Katić, B., Savić, M., (2011) Ruralni razvoj i lokalne zajednice, Ekonomika poljoprivrede, br. 1, 33-45.

Republički zavod za razvoj (2009) Strategija prostornog razvoja Republike Srbije 20092013-2020, Beograd.

Ristić, L., (2013) Strategijsko upravljanje održivim ruralnim razvojem u Republici Srbiji, Ekonomski horizonti, br. 3, 229-243.

Ristić, L., Vujičić, M., (2011) Strateški pravci ruralnog razvoja Srbije, Časopis za ekonomiju i tržišne komunikacije, br. 1, 63-73.

Spalević, A., (2009) Mogućnosti za razvoj ruralnog područja u Republici Srbiji, Geografski institut „Jovan Cvijić“ Sanu, Georafski fakultet u Beogradu, knj. 59, No 2, 133-147.

Stojanović, Ž., Manić, E. (2009) Održivi ruralni razvoj i prekogranična saradnja. Glasnik srpskog geografskog društva, br. 2, 43-64. 
Vlada Republike Srbije (2010) Zakon o Prostornom planu Republike Srbije od 2010. do 2020. godine, Službeni glasnik Republike Srbije, br. 88.

Vlada Republike Srbije (2014) Strategija poljoprivrede i ruralnog razvoja Republike Srbije 2014- 2024, Službeni glasnik RS, br. 85.

World Commission on Environment and Development (WCED) (1987), Our common future, Report of the World Commission on Environment and Development, Oxford University Press, Oxford.

www.invest.negotin.rs

www.minpolj.gov.rs 